\title{
After the "Starchitect:" Wright Finds his Voice after Being Fired
}

\author{
By Michael O'Brien *
}

The term "Starchitect" seems to have originated in the 1940's to describe a "film star who has designed a house" but of late has been understood as an architect who has risen to celebrity status in the general culture. Louis Sullivan, like Daniel Burnham, might have been considered a "starchitect." Starchitects are frequently associated with a unique style or approach to architecture and all who work for them, adopt this style as their own as a matter of employment. Frank Lloyd Wright was one of these architects, working under and in the idiom of Louis Sullivan for six years, learning to draw and develop motifs in the style of Louis Sullivan. Frank Lloyd Wright's firing by Louis Sullivan in 1893 and his rapidly growing family set him on an urgent course to seek his own voice. The bootleg houses, designed outside the contract terms Wright had with Adler and Sullivan caused the separation, likely fueled by both Sullivan and Wright's ego, which left Wright alone, separated from his "Lieber Meister" or "Beloved Master." These early houses by Wright were adaptations of various styles popular in the times, Neo-Colonial for Blossom, Victorian for Parker and Gale, each, as Wright explained were not "radical" because "I could not follow up on them.", Wright, like many young architects, had not yet codified his ideas and strategies for activating space and form. How does one undertake the search for one's language of these architectural essentials? Does one randomly pursue a course of trial and error casting about through images that capture one's attention? Do we restrict our voice to that which has already been voiced in history? Wright's agenda would have included the merging of space and enclosure with site and nature structured as he understood it from Sullivan's Ornament. While the houses that followed Wright's departure from Sullivan lack the formal coherence of the skillfully adapted "Bootleg" houses, these transitional houses constitute important markers of Wright's practice-based research towards finding a harmonious relation between plan and section, space and mass, a structure for form and space. Practice based design research is essential to architects and architecture and can offer students and new practitioners a strategy to accelerate their own growth. Frank Lloyd Wright's hundreds of houses offer a unique glimpse into the development of an expression of beliefs in form and space. This paper will present a timeline and study of Wright's earliest, sometimes awkward steps, and propose that it is an ornamental structure, learned by Wright at the desk of Sullivan, was the catalytic force that freed Wright from historicism and set him on a path of clear principle that would deeply influence the works that have made him a Master.

"Professor, Texas A\&M University, USA.

1. P. Blake, Frank Lloyd Wright: Architecture and Space (Baltimore, Md: Penguin Books, 1969), 26.

2. F. L. Wright, An Autobiography: Frank Lloyd Wright (London, New York [etc.]: Longman's, Green and Company), 1932, 110. 


\section{Introduction}

Scholars often treat Frank Lloyd Wright as boy genius, ${ }^{3}$ producing innovative designs from his first moments as an independent architect but the historical record shows otherwise. A close examination of the early years surrounding his departure from Adler and Sullivan reveals an intense struggle for voice. Wright's experiments with form, space, and structure as seen in the architect's language of plan and section show his movement away from the Classical and Victorian influences of his "Bootleg" houses towards a more original structure based largely in the lessons he learned as a draughtsman in the employ of Adler and Sullivan from 1887 to 1893.

It is the thesis of this paper that the combined factors of Wright losing his position at Adler and Sullivan, his recent marriage to Catherine Tobin, and the quickly-growing family pressed Wright into a series of practiced-based design research undertakings to learn how to master the structural organization of space, mass, and movement into the form that architectural history now labels as the Prairie House.

\section{Research Defined}

The Oxford English Dictionary defines research as "The Act of searching carefully for or pursuing a specified thing or person." As well as [A] Systematic investigation or inquiry aimed at contributing to knowledge of a theory, topic, etc., by careful consideration, observation or study of a subject. ${ }^{4}$ If we consider each commission an architect undertakes as a step towards a new understanding of the relation of type, space, and form in the emerging poetics of the American voice, then the careful, commission by commission search for the integration of fluid space and form that Wright intuited from the fusion of the geometric and the organic in Louis Sullivan's ornament can be understood as a research agenda based on the active practice of architecture.

Practice Based Research is it Necessary?

The definitions above show that research may be either goal or methodologically oriented and may be reached either systematically or by "consideration, observation, or study." "Forming and Framing" are the words Laurene Vaughan use. ${ }^{5}$ Unlike many Ph.D. students, practicing architects, beginning architects and students, the difficulty of defining the goal that is the desired outcome of the research is seldom undertaken as a search for principles. Indeed by not asking the hard questions about beliefs and instead,

3. G. C. Manson, Frank Lloyd Wright to 1910: The First Golden Age. Grant Carpenter Manson (New York: Van Nostrand Reinhold, 1970).

4. J. A. Simpson and E. S. C. Weiner, The Oxford English Dictionary. $2^{\text {nd }}$ Edition (New York/Oxford: Clarendon Press/Oxford University Press), 1989.

5. L. Vaughan, Practice-Based Design Research (London: Bloomsbury Academic, 2017). 
choosing a school, or an architecture firm based on visual appearances and blindly following along, the beginner is freed from having to establish a programme or set of principles of their own.

By not questioning more than a benefits package given with employment, or an accreditation status given to a curriculum, the beginning architect never has to confront the difficulty of the conversion of belief to form and space. The contemporary condition that traps all too many beginning architects is one of complacency, perhaps like the job security Wright felt when he earned his contract with Adler and Sullivan. ${ }^{6}$ Wright's marriage to Catherine Tobin, made possible by his secure employment with Sullivan, led to yet another financial bond with Sullivan in the form of a loan for the purchase of land and the construction of the Oak Park house. ${ }^{7}$ It was Wright's propensity for the beautiful that led to "extras" added to the cost of the house, at once exceeding the amount of the loan from Sullivan, and provoking Wright into beginning his independent practice. ${ }^{8}$

There is a cultural expectation that for a study to be considered "research" it must adhere to science-based models of inquiry, that is, "a systematic investigation, leading to greater knowledge or understanding of phenomena and of observable facts." Implicit in this is the repeatability of the research to achieve the same result. This repeatability aspect is frequently used in University promotion and tenure discussions to negate the idea of design as research, and to be fair, often design is simply a re-aggregation of knowns with little or no aspiration for discovery. Yet the pursuit of the beautiful seems to have at one time been accepted as basic research. Even the National Science Foundation includes the following 1852 quote by Joseph Henry in an appendix where the definition of research is to be found.

"The true, the beautiful, as well as the immediately practical, are all entitled to a share of attention. All knowledge is profitable; profitable in its ennobling effect on the character, in the pleasure it imparts in its acquisition, as well as in the power it gives over the operations of mind and matter. All knowledge is useful; every part of this complex system of nature is connected with every other. Nothing is isolated. The discovery of to-day, which appears unconnected with any useful process, may, in the course of a few years, become the fruitful source of a thousand inventions. "10

Perhaps the origin of a "starchitect," an architect who's unique vision and expression finds broad acceptance by the contemporary culture, begins with

6. Wright, An Autobiography: Frank Lloyd Wright, 1932, 100.

7. Ibid, 106.

8. Ibid; Blake, Frank Lloyd Wright: Architecture and Space, 1969, 31.

9. The National Science Foundation. "Appendix D Definitions of Basic, Applied, and Fundamental Research." No Author listed, No Date listed. Retrieved from https://www.nap.edu/read/11177/chapter/8\#50. Accessed [9 January 2017], 44.

10. Ibid, 50. 
practice-based-research. A programme or investigation across the boundaries of a commission to guide all the commissions of a firm such as Louis Kahn has done with the pursuit of presence, or SHOP has done with advanced fabrication, or the pursuit of the sublime by Sanaa. In each office, the question was advanced through the careful search, systematically undertaken to question every aspect of a project from aesthetics to representation to nature, mass, material, light, space and movement.

I believe practice-based research to be the key differentiator between a work of architecture and an act of building. The application of a programme having enough substance to guide every aspect of the work both differentiates building from architecture and in this way, practice-based-research is a necessity in any work of architecture, and critical to the development of Wright's architectural theory and voice following his termination by Louis Sullivan.

\section{Wright's Preparation for Architecture}

Family

Frank Lloyd Wright was born in Richland Center Wisconsin between June 81867 and June 81869 , there seems to be some confusion on the true date/year of his birth vs. the 1869 date Wright himself would cite in interviews with most historians agreeing on the 1867 date. ${ }^{11} \mathrm{He}$ was the eldest of three children born to Anna Lloyd-Jones and William Wright who abandoned his family when Frank was fifteen. William's influence on the family seems to have been in immersing the family home in music, an art form Wright would keep with him throughout his life. ${ }^{12}$

Wright's mother, Anna, was the dominant force in his life from his earliest memory to her death in 1923. She is said to have been convinced Frank would become an architect from the earliest moments of her pregnancy and became a proponent of Fredrick Froebel's Kindergarten method of education using "gifts and occupations" to instill in young Frank that design was play, and play was learning. ${ }^{13}$ Froebel was an early proponent of the Kindergarten, and believed that undertaking creative endeavors were central to learning, even at the earliest ages. ${ }^{14}$ These creative endeavors were undertaken through a series of "gifts" provided for the child, and with instruction provided through rhyme and song, the student undertook the "occupations" as Froebel termed the lessons. The Froebel gifts were a series of geometric solids, cubes, spheres, cylinders, and rectangles, each made up of smaller components so that the form and shape of the gift was changeable as the student "played" at the vital endeavor of

11. Blake, Frank Lloyd Wright: Architecture and Space, 1969, 12.

12. Ibid, 14.

13. Manson, Frank Lloyd Wright to 1910: The First Golden Age. Grant Carpenter Manson, 1970.

14. M. Ediger, Language Arts Curriculum in the Elementary School (Kirksville, Missouri: Simpson Publishing Company, 1988). 
creative making. ${ }^{15}$ It was the Froebel block gifts, number 3 through 6 , blocks made in 1:1, 1:2 and 1:4 proportions that seem to be most present in his "Prairie Period" houses.

Throughout his career, Wright credited the Froebel education as central to his ideas about form, structure and the scalability of each to be furniture, building or townscape. ${ }^{16}$ Peter Blake, in his book "Frank Lloyd Wright Architecture and Space" credits or blames Anna with imbuing Wright with an enduring arrogance, a trait that made his declarations on nature and form seem all the more plausible. ${ }^{17}$

\section{Formal Training}

Wright's mother Anna had become a teacher in the Richland Center area and home-schooled Wright in the Froebel system during his early years she saved money to send Frank to the University of Wisconsin's civil engineering program.

Anna Lloyd-Jones vision of Frank becoming an architect met the hard realities of the family's limited finances when she enrolled Frank at the University of Wisconsin, Wright himself remembers "Architecture-at first his mother's inspiration, then naturally enough his own desire, was the study he wanted. But there was no money to go away to an architectural school.",18 Wright's mother placed Frank in the employ of the Dean of the Civil Engineering School's private practice which funded Frank's room and board, while leaving him time to study. Wright's characterizes the memories of his time in the university as "mostly dull pain" 19 with the exception of mathematics, which Wright saw as having great poetic potential, but unrealized by his professor. Even at this age, Wright was deeply interested in developing his own voice, he writes "The youth [Wright himself] yearned to read and write his own language-yearned to speak it-supremely well." 20 He records selfcriticism of his writing noting that while the professor gave him "good" marks and notations like "thought excellent," while Wright himself believed his paper to be "dishwater." Wright concludes this text on his composition course by saying "He [Wright] was left to find out for himself if he could [find the limitations of language and turn them to advantages] and without material." This is the first indication of a process towards finding his own personal expression, learning the limits of a context, and learning how to turn them to his advantage. He would later undertake much the same process after being fired by Sullivan and having to put food on the table for his family without compromising his personal expression and without "any material" to guide him step by step through the process.

15. Ibid, 10.

16. Blake, Frank Lloyd Wright: Architecture and Space, 1969, 16.

17. Ibid, 14.

18. Wright, An Autobiography: Frank Lloyd Wright, 1932, 52.

19. Ibid, 52.

20. Ibid. 
Wright's life-long opposition to the classical tradition ${ }^{21}$ seems to begin in his senior year, where he recounts his frustration with Goethe and his "Classical" course was critiqued as "the very practice of the inappropriate; so any human edifice reared up on it was likely to fall down like the Capitol. Gestures were fine but - how about work? Reality?"22

Wright's autobiography recounts his internal struggle with feeling that his time at the university was being wasted, that he was a drain on the family finances, and his hope that his uncle Lloyd, a Unitarian minister in Chicago, building a new church, could get him placed with an architect's firm all combined to Wright leaving for Chicago, without his mother's knowledge or consent, and without finishing his university degree. ${ }^{23}$

Apprenticeship with Silsbee

It would be accurate to say that Wright's first apprenticeship had been with Professor Conoyer, the Dean of Civil Engineering, but his first architectural apprenticeship was in the office of J. Lyman Silsbee, Architect of All Souls Church, led by Wright's uncle Jenkin Lloyd Jones. The time in Silsbee's office opened Wright's eyes to the risks of the picturesque tradition, and Wright was critical of Silsbee's interest in the image of the building instead of its space and material form. This critical assessment of Silsbee is another hallmark in Wright's own process of practice-based research towards emergence following his departure from Sullivan's office. The image of the building, its spaces, and its substance would have to one. The achievement of this, through the "awkward" houses would be christened by Wright as "organic" architecture.

Wright gained much insight into how practice was conducted during his time in Silsbee's office. His friendship with Cecil Corwin helped him to acclimate to the music and theatre culture of Chicago. Wright left Silsbee's office after 3 months or so after asking for a raise and being rejected. He quickly found employment at a lesser firm, but with higher pay, being challenged to design buildings that "I should be learning to design." 24 For one of the few times in his career, Wright put aside his arrogance and left the position, telling his employer that he didn't feel ready to "give out designs." With that, he left, returned to Silsbee's office and was rehired at the pay level he initially requested. Ultimately, Silsbee's conventional approach to romanticism caused Wright to yearn for more fulfillment. ${ }^{25}$ Wright's weekends were spent with concerts, boxing, and self-study of Owen Jones's treatise on ornament, during which he made many ornamental drawings and tracings that would be the key to his employment at Adler and Sullivan.

21. V. Jr. Scully, Frank Lloyd Wright (New York: G. Braziller, 1960), 12.

22. Wright, An Autobiography: Frank Lloyd Wright, 1932, 58.

23. Ibid, 60 .

24. Ibid, 73.

25. Manson, Frank Lloyd Wright to 1910: The First Golden Age. Grant Carpenter Manson, 1970, 14. 
Apprenticeship with Sullivan

Grant Manson's account of Wright's application to Sullivan's office reveals the strength of Wright's desire to join the innovative Adler and Sullivan spending long days leading up to the interview preparing drawings of ornament in Silsbee's manner "sketchy and sentimental" as well as in his own manner, "directly and simply" to impress Sullivan. ${ }^{26}$ Such was the hunger of Wright to be a part of Sullivan's works, characterized by Manson as "Unconventional."27

Wright's own account of the beginnings of his apprenticeship at Adler and Sullivan shows an undefined job as one of the draughtsmen "one of a crowd" he notes and when queried by Paul Mueller, the supervisor as to what Sullivan told him to do, Wright responds "he didn't tell me." ${ }^{28}$ The undefined job soon changed with Sullivan assigning Wright to re-draw and re-ink one a drawing "ruined by a duffer I [Sullivan] fired Saturday." Intimidation and confrontation seemed to have been the nature of the culture in the draughting room, with Sullivan challenging and draughtsmen resigning as a normal daily ritual. Wright, however was "chosen" by Sullivan. ${ }^{29}$

Paul Sprague characterized Wright's role in Adler and Sullivan as converting Sullivan's small pencil sketches into larger scaled drawings. ${ }^{30}$ Even in this role as assistant, Wright sought out his own voice, injecting geometric motif's into Sullivan's "pure efflorescence" whenever he had a chance. ${ }^{31}$

Wright became Sullivan's trusted assistant, recruiting George Elmslie to leave Silsbee's office to join Sullivan. Wright asserted that he could design Sullivanesque ornament as well as Sullivan himself, an assertion questioned by Paul Sprague who noted "Wright's personal ornamental designs, whether for Adler \& Sullivan or for his own private commissions have demonstrated an innate sensitivity for geometrically controlled forms and a considerable lack of sympathy for Sullivan's plastic efflorescence." 32 This innate sensitivity for geometrically controlled forms, and Wright's role drawing Sullivan's ornament for 7 years combine to give Wright the thesis for his Practiced-Based-Research that would ultimately produce the Prairie House.

As Sullivan's confidence in Wright grew, he was given sole responsibility for the residential commissions that came to the office, Sullivan being more focused on the commercial and office buildings. He notes that Sullivan's own house on Lake Avenue, as well as Sullivan's house in Ocean Springs Mississippi were his designs as was the Charnley house in Mississippi, and the Charnley house on Astor Street in Chicago. Wright undertook these houses for

26. Ibid, 22.

27. Ibid, 21.

28. Wright, An Autobiography: Frank Lloyd Wright, 1932, 95.

29. Ibid, 96.

30. P. Sprague, The Architectural Ornament of Louis Sullivan and his Chief Draftsmen.

V.1. PhD Thesis (Princeton University, 1969), 116.

31. Wright, An Autobiography: Frank Lloyd Wright, 1932, 104.

32. Sprague, The Architectural Ornament of Louis Sullivan and his Chief Draftsmen, $1969,117$. 
Adler and Sullivan after hours, earning overtime to help pay for the extra's Wright included in his own home, and in the expenses of his growing family.

\section{Independent Commissions}

The "Bootleg" Houses

Ultimately Wright's expenses exceeded even the additional revenue provided by this overtime pay and he began accepting independent commissions for houses. The Harlan, Blossom, Mcharg and McArthur houses were designed with no "radical" design aspects because, as Wright records, he "could not follow up on them." 33 But these houses prove Wright's ability to transform the academic traditions into solutions for his clients. This ability to catalog and recall visual sources was described by Wright biographer Meryle Secrest who observed "Wright was influenced, all his life, by everything he saw, however much the original idea might be transmuted and transformed by the alchemy of his imagination. He may have been in the position analogous to that of someone with a powerful musical memory, that is to say, haunted by images if not actually hounded by them, until he had exhausted all their possibilities. $^{34}$

The visual differences between Wright's and Sullivan's works led to a questioning of the importance of Sullivan on Wright's blossoming in what is known as the Prairie Period with Manson writing "So much has been said, written, and inferred concerning the association of Frank Lloyd Wright and Louis Henry Sullivan that it deserves every scrutiny. Yet it is a relationship that has the qualities of a mirage; it grows less substantial the closer it is approached." 35 I hope the following evidence informs the reader that while an historian such as Manson might find this to be true based on visual similarity, architects might see more of the structural similarity Wright developed in his Practice-Based-Research with the structures of Sullivan's most essential expressions, his ornamental designs. ${ }^{36}$

So, "hounded by" images, probably from professional journals Wright's own house, and the houses for W.S. McHarg, Walter and Thomas Gale, Robert Parker skillfully transformed the Queen Ann while the George Blossom house similarly transformed the Colonial into houses for contemporary families. This ability to apply "academic discipline" to his works would come to the attention of Daniel Burnham and lead to an invitation to study at the Ecole des Beaux Arts, an offer Wright ultimately rejected. Wright's account of this, Secrest's

33. Wright, An Autobiography: Frank Lloyd Wright, 1932, 110.

34. M. Secrest, Frank Lloyd Wright. $1^{\text {st }}$ ed. by Meryle Secrest (New York: Alfred A. Knopf, 1992), 118.

35. Manson, Frank Lloyd Wright to 1910: The First Golden Age. Grant Carpenter Manson, 1970, 21.

36. T. H. Beeby, "The Grammar of Ornament/Ornament as Grammar," In Ornament (ed.) Stephen Kieran, Via 3 (Philadelphia: Graduate School of Fine Arts, University of Pennsylvania, 1977), 21. 
account of this both hint at this as a rejection of the skillful stylistic adaptations as the basis of Wright's architecture leaving the stage open for the practicebased research leading Wright to his own voice, the Prairie House.

Research Agenda; after the "Bootlegs"

Following his quitting/firing from Adler and Sullivan in 1893, Wright opened his own office in space shared by friend Cecil Corwin initially, and ultimately with "the 18," a group of architects credited with developing what became known as "The Prairie School," not by the participants themselves, but by historian H. Allen Brooks. ${ }^{37}$ The term itself is not important, but the group's pursuit of a midwestern architecture, eschewing the Eastern U.S. and European academic tradition for a more personal expression principled in the celebration of the Midwest. Participation/leadership in this group was instrumental for Wright, who at this time, cast off the images of the Queen Ann and Colonial ${ }^{38}$ and began his practice-based research agenda searching for a uniquely midwestern architecture using the single-family residence as his research vehicle.

I propose that the time period for this practice-based research agenda extended from Wright's departure from Sullivan's office in 1893 to 1900. 1893 is chosen as this is the year that Wright rejects the offer of the Ecole des Beaux Arts scholarship from Daniel Burnham and effectively rejects the academic tradition (that got him fired) for something yet unknown. 1900 is chosen as a milestone, not an ending, but a point where Wright's ideas about the land, the sky, space, and family all find coherent form in the typology of the Prairie House.

From 1893 to 1900 Wright undertakes some 20 house commissions. Each is a research project negotiated between owner and architect leading to awkwardness as Wright learns the strategies of working with owner, and builder, all while reaching for something true to his beliefs, and staying a step ahead of creditors.

MacCormack discusses the Froebel lessons from Wright's youth as a base from which Wright will transform cubes of maple toys to cubes of space, a cruciform of woven patterns to a cruciform of partially defined rooms and always, like was the case in the Froebel lessons, using all the parts to make the "whole." ${ }^{39}$ MacCormack argues that the base grid for the Froebel lessons was transformed by Wright through the privileging of some grids, while erasing others, thus forming a tartan grid which contained elements such as pier, fireplace, wall, leaving the space between the elements a more pure proportion

37. H. A. Brooks, Prairie School Architecture: Studies from "The Western Architect" Edited and Introduced by H. Allen Brooks (Toronto; Buffalo: University of Toronto Press, 1975).

38. H. Hitchcock, "Frank Lloyd Wright and the 'Academic Tradition' of the Early Eighteen-Nineties." Journal of the Warburg and Courtauld Institutes 7 (1944): 50. 1968).

39. R. MacCormac, The Anatomy of Wright's Aesthetic (London: Architectural Review, 
in contrast with a Cartesian grid which always compromised proportions between elements due to material thickness. ${ }^{40}$

The earliest of Wright's houses analyzed by MacCormack is the George Blossom house from 1892. The plan is analyzed to highlight the center and cross axis on the second floor and the four corner rooms on the first, completing MacCormack's visual analogy to the cruciform outcomes of one of the Froebel lessons. He follows the Blossom analysis with the Winslow house from 1893, where his conclusion is that the underlying formal structure has a "far less explicit" relation to the Froebel lessons in both plan and elevation. The "Froebel whole" that is, in MacCormacks words, the "complete interdependence of exterior and plan" first appears in the Joseph Husser House of $1900 .^{41}$

Yet, while compelling comparisons between masses that could be constructed with the Froebel gifts were made evident by Manson and MacCormack for Wright's early institutional buildings, these formal comparisons did not hold well for Wright's houses but are compelling if one considers the cubic maple Froebel gifts as the spaces within the houses and not the house form itself.

If Wright held the Froebel lessons in one hand as a discipline for articulating spaces, I believe he held his lessons from Sullivan in the other. Wright's role in Sullivan's office began with his involvement in scaling and inking Sullivan's ornament. Wright observed Sullivan's "method" for making ornament, which in the early 1890's differed slightly in its sublimation or celebration of geometry from Sullivan's practices in the early 1920's.

Ornament for the commissions of the late 1880's and early 1890's (Wright's time in the office of Adler and Sullivan) Sullivan's sketches for ornament show that the piece would begin with the ornament's location, it's "frame" or site within the overall architectural element (arch, soffit, capital, etc.) given this frame, Sullivan would locate the primary elements of efflorescence, often geometrically related to centers or geometric subdivisions of the frame, he then would unite these elements of efflorescence with lines of growth, also following secondary aspects of the frame's geometry. ${ }^{42}$ Often these lines of growth would extend over the frame, clasping the organic expression of the efflorescence to the underlying structure of the geometrical frame much as the trellis supports the roses grown by Sullivan in his Ocean Springs Mississippi garden.

40. Brooks, Writings on Wright: Selected Comment on Frank Lloyd Wright. Edited, with Introduction and Commentary, by H. Allen Brooks, 1981, 86.

41. MacCormac, The Anatomy of Wright's Aesthetic. London, Architectural Review, 1968, 146.

42. L. H. Sullivan and P. E. Sprague, The Drawings of Louis Henry Sullivan: A Catalogue of the Frank Lloyd Wright Collection at the Avery Architectural Library, by Paul Edward Sprague; with a Foreword by Adolf K. Placzek (Princeton, N. J.: Princeton University Press, 1979), 38-52. 
Sullivan's method, was cited by apprentice Charles White in a series of letters written while he was a part of Wright's studio. Whites May 13, 1904 correspondence includes the following;

"When W. [Wright\} first came out of Sullivan's office, he very naturally put into his work much of S's [Sullivan's] method, and not a little of his ornament. Then came a period of transition, when he was trying to break away from Sullivanism, and casting about for methods of self-expression. His works of those days were interesting - and somewhat above the work of the average man, tho lacking the stability and refinement of his present work. ",3

This would seem to make the goal for Wright's practice-based research clear, to develop a whole architectural expression of the principles of growth and efflorescence learned at Sullivan's side within the ruled grids and using the clear spatial volumes used in the Froebel lessons.

If we consider Wright's residential commissions between 1892 and 1900, we should be able to observe his progress towards this research goal. The Queen Ann inspired "bootleg houses" completed in violation of Wrights contract with Sullivan as seen in Figure 1 demonstrate a vertical massing emphasis when seen from the street.

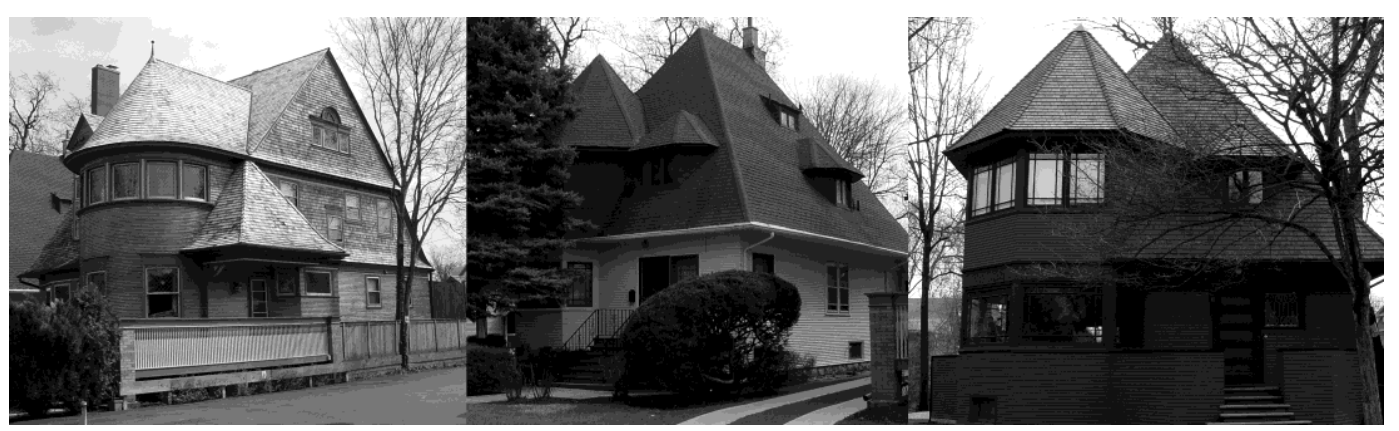

Figure 1. The Walter Gale (left) Thomas Gale (center) and Robert Parker (right) "Bootleg" Houses Share a Historicist Expression Common to Wright's Early Houses

Source: Author.

Mapping the spaces proportioned as the Froebel gifts, 1:1, 1:2 and 1:4 as they occur between the walls or elements of these early houses, we can see that the Queen Ann styled Emmonds, as shown in Figure 2, innovative as it might be as an open plan interior, maps as a functional cluster, with no apparent structure of spaces.

43. Brooks, Writings on Wright: selected comment on Frank Lloyd Wright. edited, with introduction and commentary, by H. Allen Brooks. Cambridge, 1981, 85-86. 


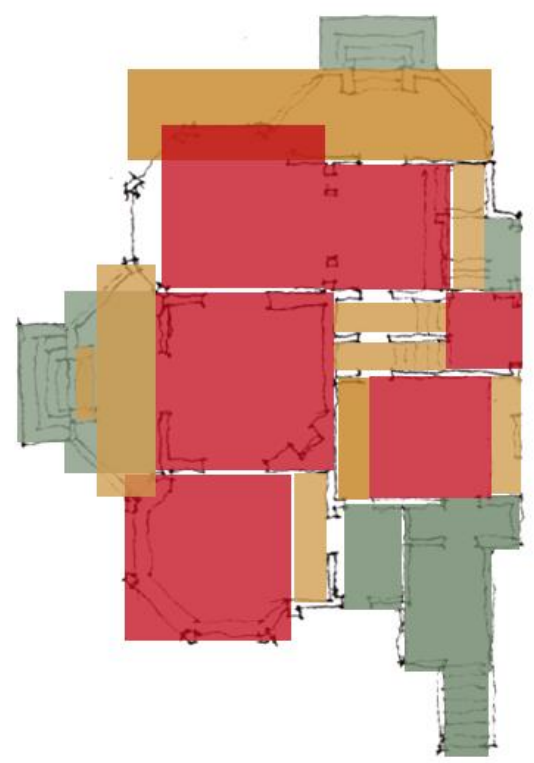

Figure 2. Emmonds House Plan 1892 Overlaid with Froebel Proportions 1:1 (red), 1:2 (green), 1:4 (ochre)

Source: Authors Sketch Plan and Diagram.

Four years later, Wright's Isadore Heller House from 1897, shown in Figure 3, shows the beginnings of structure with two offset stems of movement each leading to an important space / efflorescence, the living room and the dining room. Froebel proportions are compromised here, largely for functional reasons, indicative of Wright finding his way to balance owners needs with clear form and space.
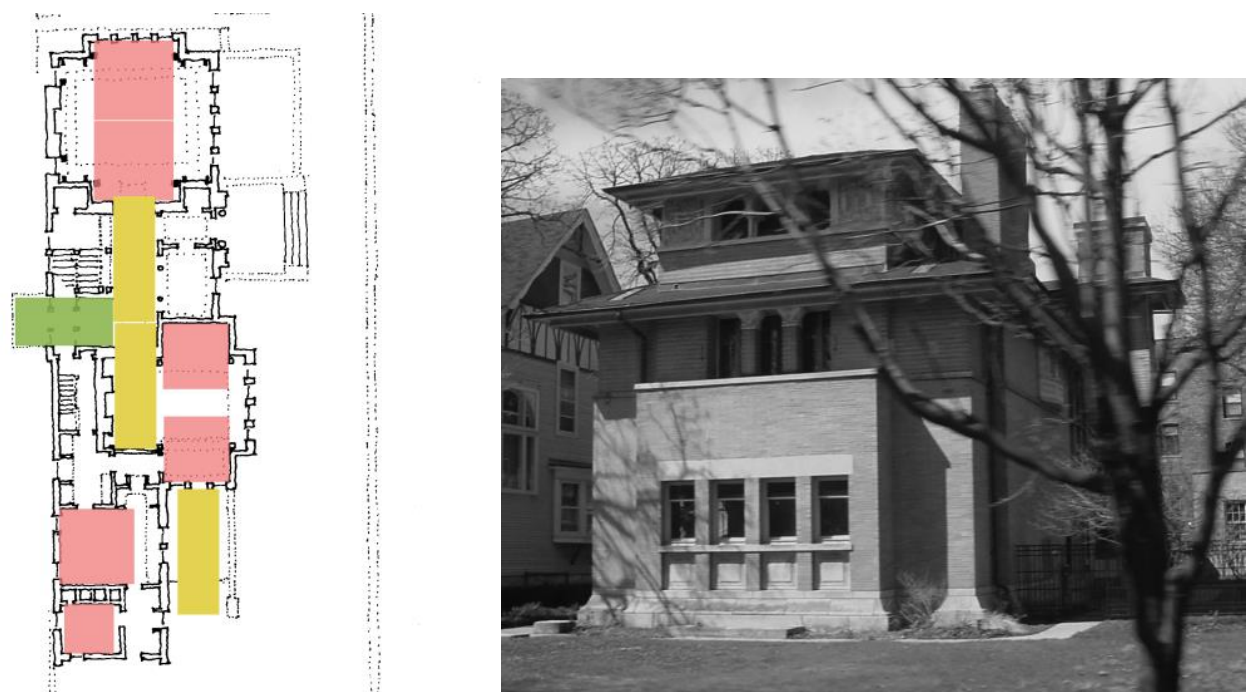

Figure 3. Isadore Heller House Plan 1896 Overlaid with Froebel Proportions 1:1 (red), 1:2 (green), 1:4 (ochre)

Source: Author Sketch Plan, Image and Diagram. 
Similarly, the George Furbeck house from 1897, seen in Figure 4, shows clear compositional intent of the plan geometries, anchored by a central octagon, with paired octagons left and right. These intentional space-forms are not yet entered by a clear structure, only a central door located under a square proportioned porch. Seen from the street, the remodeled porch awkwardly fronts the squat extrusions of the octagonal flanking spaces which are topped with conical roofs that, while clearly privileging the horizontal plane through their overhangs, never resolve with the roof (rectangular) over the larger central octagon. A clear failure in the resolution of the exterior form to the interior spaces.
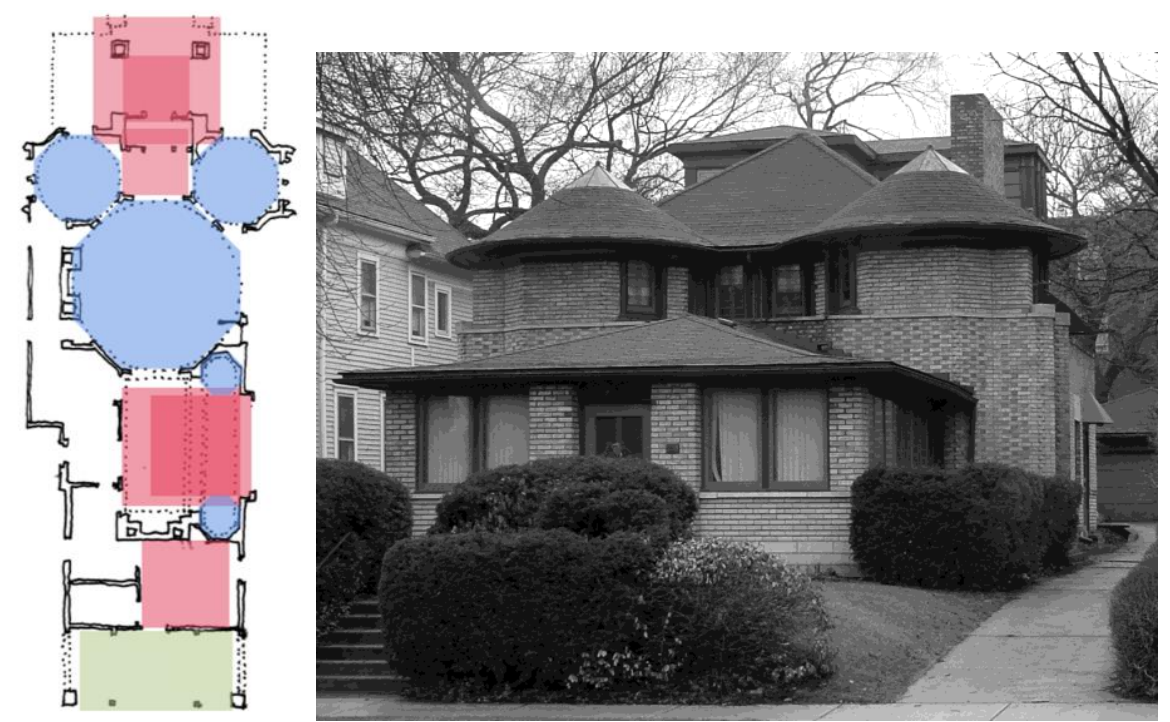

Figure 4. George Furbeck House 1897 (right) Overlaid with Froebel Proportions 1:1 (red), 1:2 (green), 1:4 (ochre) Octagons (Blue)

Wright seems to have quickly corrected his formal strategy related to the octagon with the unbuilt plan for the Aline Devin house of 1896, seen at left in Figure 5. In the Devin House Wright frees the geometry of the flanking octagons from the cubic central mass of the house, giving the plan a distinctively ornamental structure and organization, much like the Sprite called "Gift Giver" seen at left in Figure 5a, fabricated by Iannelli in close collaboration with Wright for the Midway Gardens of 1914. 

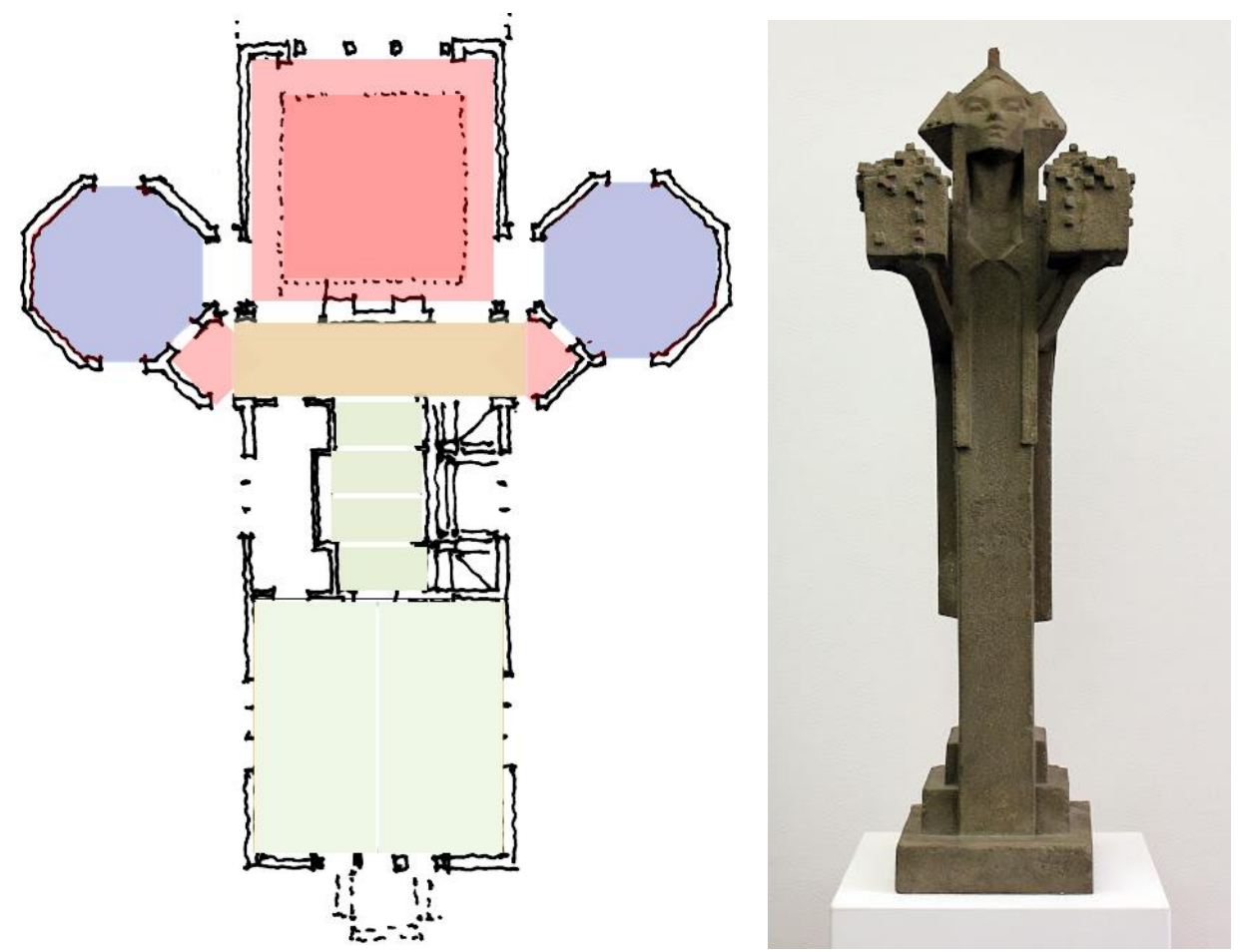

Figure 5. Aline Devin House Plan 1896 (unbuilt) (left) Overlaid with Froebel Proportions 1:1 (red), 1:2 (green), 1:4 (ochre) Octagons (Blue) a. The "Gift Giver, Alfonso Iannelli for Frank Lloyd Wright's Midway Gardens (right) Source: Authors Sketch Plan and Diagram.

The McAfee House plan of 1896, shown in Figure 6, shows a similar ornamental structure with the element of efflorescence (octagon) atop a incremented stem axis, with root efflorescence below (kitchen), this is similar to the ornamental structure from a typical "root-stem-bloom" ornament type from Sullivan shown in Figure 6a. The Bradley house plan, Figure 7, considered the beginning of the Prairie houses and when mapped to the Froebel gift proportions, reveals an off-axis efflorescence element (living room) atop an incremented stem (arcaded walkway) that suggests Wright had control over his geometrical space/forms and had the confidence to step away from rigid plan symmetry and introduce a dynamism to the space that resulted from indirect paths of movement and views from entry to the fireplace that would characterize his next 100 houses over the next 10 years. 

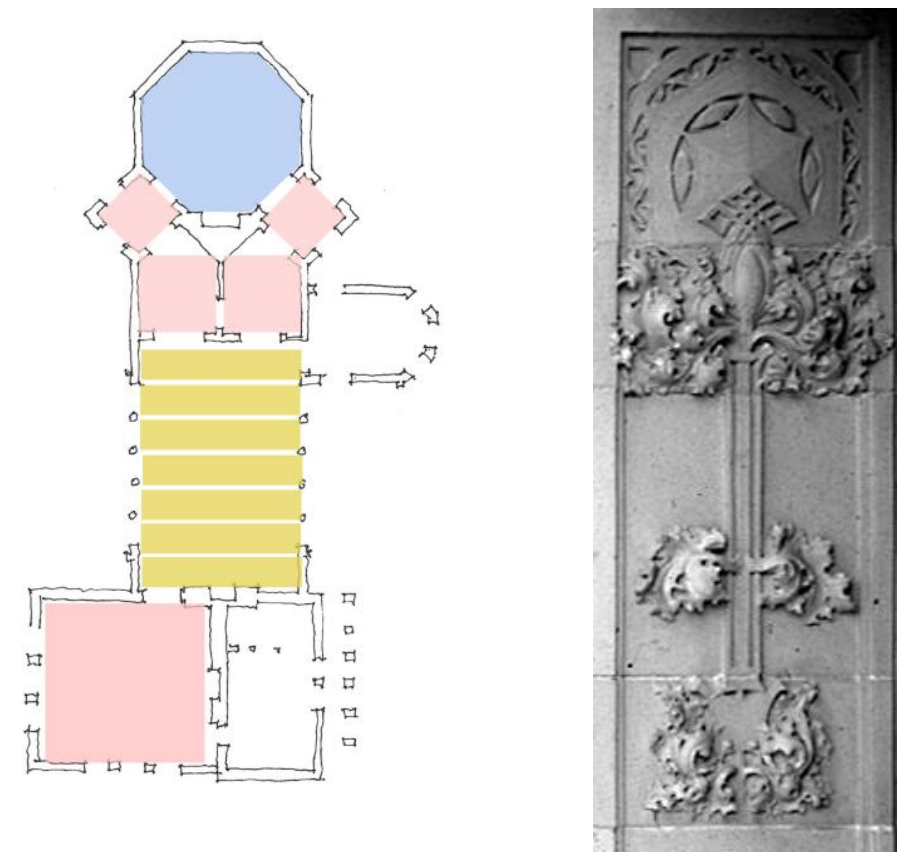

Figure 6. (left) A.C. McAffee House Plan 1894 Overlaid with Froebel Proportions 1:1 (red), 1:4 (Ochre), Octagons (Blue) a. (right) Merchants National Bank 1913 Louis Sullivan. Ornament at Entry showing Heraldic Efflorescence (octagon) atop a Incremented Stem Axis, with Root Efflorescence below

Source: Author Sketch Plan, Photograph and Diagram.

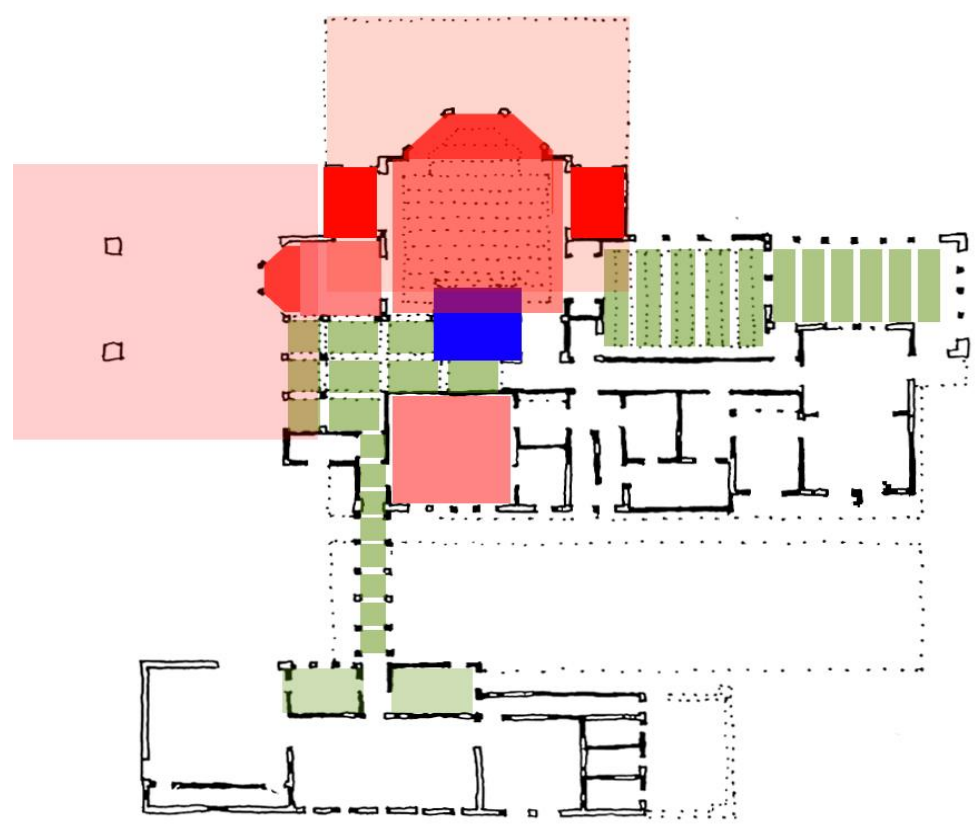

Figure 7. Bradely House Plan 1900 Overlaid with Froebel Proportions 1:1 (red), 1:2 (green), 1:4 (ochre)

Source: Author Sketch Plan and Diagram 


\section{Conclusions}

Wright's dismissal from Adler and Sullivan set him free on a path to integrate what was learned from the Froebel Kindergarten lessons about geometry, space, and form with the lessons on organicism, structure, and vitalism learned as Louis Sullivan's apprentice. The years 1893 to 1900 are marked with examples of Wright wrestling with the imposition of geometric order (from Froebel) in the context of the single-family residence, finding a coherence (unity) when he began applying the structural relationship between spaces in much the same way he developed the relationship between botanical structures (efflorescent elements) in Sullivan's ornament.

His practice-based research was developed over a series of a dozen or so commissions and was not known by his office staff with Charles White observing "then came a period of transition, when he was casting about for methods of self-expression." ${ }^{44}$ White goes on to explain that Wright would "fit the [owner's] requirements to the design" an indication that Wright understood that the clarity of geometric space and its associated exterior form, wasn't always a natural fit, and that as Wright found his voice, gained confidence he was more able to mold the owners needs to fit. This is consistent with Wright's recommendation that owners not bring furniture with them as they moved in, rather that he would have custom designed it to retain the organic wholeness of the design.

Wright is not alone in employing commissions as design research. Mies van der Rohe undertakes a similar practice-based research path to his own voice following his departure from the practice of Peter Behrens in 1911. His Urbig House of 1917 follows a mannerist approach as did his Riehl House of 1907. ${ }^{45}$ His unbuilt 1921 proposals for the glass skyscraper and the Friedrichstrasse Office building are the first architectural proposals breaking free of the constraints of the technology of the European wall plane which Mies continued developing in his Weissenhof housing and Afrikanischestrasse housing through 1927. The transparency of the Friedrichstrasse returns in the German Pavilion construction in Barcelona in 1929 and opens a new spatial direction which he would continue integrating with his steel and glass transparent blocks designed for both the office and educational typologies. ${ }^{46}$

Practice-based research in architectural design is often easier to comprehend after the number of experimental projects reaches a few dozen, particularly if those fall within a concentrated period of time, observations of plan, section, elevation can reveal a series of successes, but perhaps more importantly, reveal the failures as perceived by the architect, which tell us more about how design success occurs. Failures, particularly those accompanied by

44. Brooks, Prairie School Architecture: Studies from "The Western Architect” Edited and Introduced by H. Allen Brooks, 1975, 87.

45. A. Drexler, Ludwig Mies van der Rohe (New York: G. Braziller, 1960), 11.

46. D. A. Spaeth, Mies van der Rohe. David Spaeth; Preface by Kenneth Frampton (New York: Rizzoli, 1985), 120-135. 
the kinds of financial stress brought on by dismissal, family growth, and the capriciousness of the national economy are a powerful motivating force driving practice-based research for small practitioners like Frank Lloyd Wright.

\section{Bibliography}

Beeby, T. H. "The Grammar of Ornament/Ornament as Grammar." In Ornament. Edited by Stephen Kieran, Via 3. Philadelphia: Graduate School of Fine Arts, University of Pennsylvania, 1977.

Blake, P. Frank Lloyd Wright: Architecture and Space. Baltimore, Md: Penguin Books, 1969.

Brooks, H. A. Prairie School Architecture: Studies from "The Western Architect" Edited and Introduced by H. Allen Brooks. Toronto; Buffalo: University of Toronto Press, 1975.

Drexler, A. Ludwig Mies van der Rohe. New York: G. Braziller, 1960.

Ediger, M. Language Arts Curriculum in the Elementary School. Kirksville, Missouri: Simpson Publishing Company, 1988.

Hitchcock, H. "Frank Lloyd Wright and the 'Academic Tradition' of the Early Eighteen-Nineties." Journal of the Warburg and Courtauld Institutes 7 (1944): 46-63. doi: 10.2307/750380.

MacCormac, R. The Anatomy of Wright's Aesthetic. London: Architectural Review, 1968, 143-146.

Manson, G. C. Frank Lloyd Wright to 1910: The First Golden Age. Grant Carpenter Manson. New York: Van Nostrand Reinhold, 1970.

Scully, V., Jr. Frank Lloyd Wright. New York: G. Braziller, 1960.

Secrest, M. Frank Lloyd Wright. $1^{\text {st }}$ ed. by Meryle Secrest. New York: Alfred A. Knopf, 1992.

Simpson, J. A. and E. S. C. Weiner. The Oxford English Dictionary. $2^{\text {nd }}$ Edition. Oxford/ New York: Clarendon Press/Oxford University Press, 1989.

Spaeth, A. Mies van der Rohe. David Spaeth; Preface by Kenneth Frampton. New York: Rizzoli, 1985, 120-135.

Sprague, P. The Architectural Ornament of Louis Sullivan and his Chief Draftsmen. V.1. PhD Thesis. Princeton University, 1969.

Sullivan, L. H. and P. E. Sprague. The Drawings of Louis Henry Sullivan: A Catalogue of the Frank Lloyd Wright Collection at the Avery Architectural Library, by Paul Edward Sprague; with a Foreword by Adolf K. Placzek. Princeton, N. J.: Princeton University Press, 1979, 38-52.

The National Science Foundation. "Appendix D Definitions of Basic, Applied, and Fundamental Research." No Author listed, No Date listed. Retrieved from https://www.nap.edu/read/11177/chapter/8\#50. Accessed [9 January 2017].

Vaughan, L. Practice-Based Design Research. London: Bloomsbury Academic, 2017.

Wright, F. L. An Autobiography: Frank Lloyd Wright. London, New York [etc.]: Longman's, Green and company, 1932. 
